\title{
V MIĘDZYNARODOWA KONFERENCJA NAUKOWA Z CYKLU „UKRAINISTYKA: WCZORAJ, DZISIAJ, JUTRO...”
}

\author{
DOMINIKA JANCZURA \\ Uniwersytet im. Adama Mickiewicza w Poznaniu, Poznań - Polska \\ dominikajanczura@interia.eu; ORCID: 0000-0001-5634-7044 \\ V МІЖНАРОДНА НАУКОВА КОНФЕРЕНЦІЯ
„УКРАІНІСТИКА: ВЧОРА, СЬОГОДНІ, ЗАВТРА...” \\ ДОМІНІКА ЯНЧУРА \\ Університет ім. Адама Міцкевича в Познані, Познань - Польща
}

\begin{abstract}
АНОТАЦІЯ. Стаття присвячена ознайомленню читачів з роботою V Міжнародної Наукової Конференції „Україністика: вчора, сьогодні, завтра...”, організованої щодва роки Кафедрою Україністики Університету ім. Адама Міцкевича в Познані. Конференція відбулася 22-23 жовтня 2020 року і повністю була проведена в онлайн-форматі, для роботи використано платформу Майкрософт Тімс. У конференції брало участь 47 вчених з Польщі і з-за кордону. Наукову зустріч було поділено на п’ять різноаспектних секцій, робочими мовами визначено польську й українську. Конференція мала на меті обговорення актуальних питань україністики у широкому значенні цього поняття - мовознавства, літературознавства, культурології. Акордом конференції став круглий стіл „Український нуар і творчість Олеся Ульяненка”.
\end{abstract}

Ключові слова: конференція, україністика, мовознавство, літературознавство, культурологія, тематична секція 


\title{
5TH INTERNATIONAL SCIENTIFIC CONFERENCE „UKRAINIAN STUDIES: YESTERDAY, TODAY, TOMORROW ...”
}

\author{
DOMINIKA JANCZURA \\ Adam Mickiewicz University, Poznań, Poznań - Poland
}

\begin{abstract}
This article presents the course of the 5th International Scientific Conference "Ukrainian studies: yesterday, today, tomorrow..." work, which is organized every two years by the Department of Ukrainian Studies at Adam Mickiewicz University. The conference took place on October 22-23, 2020 and was entirely online, using the Microsoft Teams platform. 47 researchers from Poland and abroad participated in the conference. The meetings were divided into five different thematic sections, the languages of the sessions were Polish and Ukrainian. The aim of the conference was to discuss the current problems of Ukrainian studies, including linguistics, literary studies, culturology. The culmination of the conference was round table discussion "Ukrainian noir and Oles Ulyanenko's creative work".
\end{abstract}

Keywords: conference, Ukrainian studies, linguistics, literary studies, culturology, thematic sections

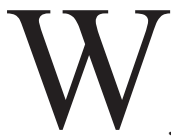
dniach 22-23 października 2020 miała miejsce V Międzynarodowa Konferencja Naukowa z cyklu „Ukrainistyka: wczoraj, dzisiaj, jutro..." zorganizowana przez Zakład Ukrainistyki Uniwersytetu im. Adama Mickiewicza w Poznaniu. Konferencja odbywa się tradycyjnie co dwa lata i jednoczy badaczy z różnych ośrodków naukowych. Spotkanie ma na celu omówienie aktualnych problemów ukrainistyki, ze szczególnym uwzględnieniem językoznawstwa, literaturoznawstwa, kulturologii oraz nauk pokrewnych. W tym roku ze względu na panujące obostrzenia związane z pandemią, uniemożliwiające przyjazd oraz przyjęcie w murach Uniwersytetu wielu gości z zagranicy, konferencja została przeprowadzona $\mathrm{w}$ trybie online. Zmiana ta została przyjęta ze zrozumieniem, a sami uczestnicy chętnie zaangażowali się w nowy format konferencji. Możemy śmiało przyznać, że mimo przeszkód wirtualne spotkanie ukrainistów było niezwykle owocne.

Wszystkie obrady były prowadzone na platformie Microsoft Teams, która wykorzystywana jest przez UAM w okresie obowiązywania stanu pandemii. W konferencji wzięło udział 45 uczestników i uczestniczek z trzech krajów (Polska, Ukraina, Słowacja). Byli wśród nich profesorowie (3), doktorzy habilitowani (2), doktorzy nauk (8), doktorzy albo kandydaci nauk humanistycznych (22), ale również doktoranci (8). Językiem konferencji był polski i ukraiński. Uczestnicy reprezentowali czołowe ośrodki naukowe Polski: Instytut Slawistyki Polskiej Akademii Nauk, Uniwersytet Jagielloński (Kraków), Uniwersytet Wrocławski, Uniwersytet im. Adama Mickiewicza w Poznaniu; Słowacji: Uniwersytet 
Komeńskiego w Bratysławie oraz liczne instytucje naukowe Ukrainy, m.in.: Instytut Językoznawstwa im. Aleksandra Potebni oraz Instytut Literatury im. Tarasa Szewczenki Narodowej Akademii Nauk Ukrainy, Kijowski Uniwersytet Narodowy im. Tarasa Szewczenki, Kijowski Narodowy Uniwersytet Lingwistyczny, Narodowy Uniwersytet „Akademia Ostrogska”, Narodowy Uniwersytet im. Iwana Ohijenki w Kamieńcu Podolskim, Doniecki Uniwersytet Narodowy im. Wasyla Stusa (ostatnio przeniesiony do Winnicy), Użhorodzki Uniwersytet Narodowy, Zaporoski Państwowy Uniwersytet Medyczny, Sumski Państwowy Uniwersytet Pedagogiczny im. Antona Makarenki, Tarnopolski Narodowy Uniwersytet im. Wołodymyra Hnatiuka, Rówieński Państwowy Uniwersytet Humanistyczny, Ługański Uniwersytet Narodowy im. Tarasa Szewczenki, Uniwersytet Celny i Finansowy w Dnieprze (byłym Dniepropietrowsku).

Uczestników konferencji przywitał dyrektor Instytutu Filologii Rosyjskiej i Ukraińskiej UAM dr hab. prof. UAM Wawrzyniec Popiel-Machnicki, który podkreślił, jak duże znaczenie mają studia ukrainistyczne w życiu uniwersytetu. Uroczystego otwarcia konferencji dokonali dziekan Wydziału Neofilologii prof. Krzysztof Stroński oraz prodziekan prof. Andrzej Narloch, którzy zgodnie podkreślili aktualność bliskich kontaktów z Ukrainą w sferze nauki i kultury oraz życzyli gościom owocnej pracy podczas kolejnych obrad. Dzięki prezentacji przygotowanej przez prof. Tetianę Kosmedę, kierowniczkę Zakładu Ukrainistyki, mogliśmy wrócić wspomnieniami do poprzednich spotkań naukowych z cyklu „Ukrainistyka: wczoraj, dzisiaj, jutro...”. Profesorka dołączyła się również do życzeń przedmówców. Moderatorem uroczystego otwarcia konferencji był profesor Zakładu Ukrainistyki Jarosław Poliszczuk, reprezentujący komitet organizacyjny tego wydarzenia. Funkcję sekretarki naukowej konferencji z powodzeniem pełniła doktorka Otena Kowalewska.

Podczas obrad plenarnych uczestnicy mogli wysłuchać siedmiu prelekcji przedstawiających różne aspekty współczesnych badań ukrainistycznych. Kandydatka nauk filologicznych, starsza pracowniczka naukowa Instytutu Językoznawstwa im. Aleksandra Potebni Narodowej Akademii Nauk Ukrainy Oksana Mychalczuk (Kijów) poruszyła budzącą niepokój zarówno wśród naukowców, jak i w opinii publicznej kwestię tożsamości językowej wspólnot etnicznych w kontekście sytuacji językowej w Ukrainie. Profesorka dr hab. Tetiana Kosmeda (Poznań) scharakteryzowała status języka ukraińskiego, odwołując się do ocen znanych postaci historycznych i współczesnych badaczy. Profesorka dr hab. Ludmyła Marczuk (Kamieniec Podolski) omówiła pojęcie normy $\mathrm{w}$ teorii gramatyki funkcjonalnej, głównie w dwu aspektach - filozoficznym i lingwistycznym. Profesorka dr hab. Hałyna Łukasz (Donieck - Winnica) przedstawiła teorię onimii konotatywnej w ukraińskiej onomastyce. Profesorka dr hab. Iryna Zacharczuk (Równe) kompetentnie i emocjonalnie przeanalizowała skutki traumy związanej z Wielkim Głodem w doświadczeniach współczesnej 
literatury ukraińskiej. Profesorka dr hab. Katarzyna Kotyńska (Warszawa) zajęła się aktualnym problemem przekładoznawstwa, ustalając warianty „trzeciego języka" w przekładzie artystycznym; problem dotyczył w szczególności włączania języka rosyjskiego do ukraińskich tekstów literackich. Profesorka dr hab. Tetiania Hrebeniuk (Zaporoże) przedstawiła amerykańską koncepcję „nowej szczerości” oraz możliwość zastosowania jej w interpretacji powieści Sofii Andruchowycz Amadoka. Sesja plenarna zakończyła się szeroką dyskusją wokół wymienionych poglądów naukowych i tez badawczych.

Kolejne spotkania odbyły się w pięciu sekcjach, odzwierciedlających konkretne zainteresowania naukowe uczestników. W sekcji pierwszej - „Tradycje ukraińskiego językoznawstwa oraz współczesność. Studium praktyk dyskursywnych" - zostały omówione ogólne problemy współczesnej lingwistyki. Kandydatka nauk filologicznych, starsza pracowniczka naukowa Lilija Andrijenko (Kijów) skupiła uwagę na badaniu żywotności języków mniejszości Ukrainy, ukazując wcześniejsze wyniki badań nad tą kwestią, jak również perspektywy na przyszłość. Doktorantka Jana Żurenko snuła rozważania na temat lingwistyki płci - wciąż niedostatecznie rozpoznanej, zwłaszcza w Ukrainie. Badaczka porównała skromne doświadczenie rodzime z osiągnięciami w tym zakresie w nauce światowej. Doktorantka Maria Muzyka (Kijów) analizowała teoretyczne założenia stosunku Ukraińców do języka ojczystego. Doktorka Julia Rysicz-Szafraniec (Wrocław) poświęciła swoje wystąpienie surżykowi oraz jego recepcji w środowisku jednojęzycznym. Doktor Łukasz Małecki (Poznań) zapoznał obecnych z przestrzenią semantyczną leksemu 'fejk', który pomimo że pojawił się w języku mass mediów stosunkowo niedawno, dziś stosowany jest na szeroką skalę. Doktorantka Maria Ostapenko (Kijów) starała się ujawnić potencjał sugestywny eponimów we współczesnym dyskursie politycznym, a kandydat nauk filologicznych, docent Borys Kowalenko (Kamieniec Podolski) przedstawił stan badań nad językiem utworów XIX-wiecznego ukraińskiego poety i tłumacza Stepana Rudańskiego. Badacz skupił uwagę na analizie rękopisów pisarza oraz praktyce publikowania jego dzieł.

W sekcji drugiej spotkali się badacze problematyki komparatystycznej języka polskiego i ukraińskiego, a także wykładowcy zajmujący się problemem wzajemnego wpływu obu języków na terenie Polski. Doktorka Olga Barabasz-Rewak (Wrocław) zbadała językową reprezentację atrybutów Boga na przykładzie wybranych psalmów w ukraińskim przekładzie Iwana Ohijenki. Doktorka Wiktoria Hojsak (Kraków) przeanalizowała derywaty przymiotnikowe i przysłówkowe leksemów 'село'/'wieś' we współczesnym języku ukraińskim i polskim. Doktorka Helena Sojka-Masztalerz (Wrocław) zestawiła zooinwektywy w różnych wariantach obu języków. Doktorka Otena Kowalewska (Poznań) poświęciła uwagę wykorzystaniu feminatywów w nazwach zawodów medycznych zarówno w języku polskim, jak i ukraińskim. Doktorka Marija Red'kwa (Kraków) zaproponowała 
innowacyjne podejście do badań porównawczych nad językiem: przeanalizowała przyswojenie etnokodu ukraińskich bajek ludowych przez dzieci dwujęzyczne. Kandydatka nauk filologicznych Olha Fed'ko (Zaporoże) zbadała na przykładzie języka ukraińskiego i polskiego cechy nauczania i uczenia się języka flektywnego jak obcego.

W sekcji trzeciej zatytułowanej „Aspekty funkcjonalne współczesnego językoznawstwa oraz nauczanie języka ukraińskiego jako obcego" wybrzmiało siedem referatów. Kandydatka nauk filologicznych Iryna Braha (Sumy) zaproponowała analizę niekodyfikowanej mowy codziennej w komunikacji międzyrodzinnej. Iryna Bożko (Sumy), kandydatka nauk filologicznych, scharakteryzowała quasi-toponimy oraz toponimy konotatywne wykorzystywane przy tworzeniu regionalizmów. Swoje rozważania na temat problemów współczesnej fonetyki przedstawiła w interesującym wystąpieniu pt. „Transformacje struktury fonemicznej słowa fonetycznego jako przyczyna nieporozumień w komunikacji" kandydatka nauk filologicznych Wira Berkowec' (Kijów). Kolejna prelegentka, również kandydatka nauk filologicznych, Natalia Kowalenko (Kamieniec Podolski) zbadała kontekstualność frazemów na przykładach ukraińskich dialektyzmów. Kandydatka nauk filologicznych, docentka Swittana Derba (Kijów) opowiedziała o rozwoju umiejętności komunikacyjnych studentów zagranicznych metodą słuchania. Specyfikę metody komunikacyjnej w profesjonalnym podejściu do nauczania języka ukraińskiego jako obcego przedstawiła w swym referacie docentka Tetiana Lach (Użhorod). Docentka Olha Petryszyna (Tarnopol) poświęciła swój występ współczesnej, wciąż mało zbadanej, praktyce komunikacji na portalach społecznościowych, przy czym oceniła ową komunikację w paradygmacie komunikacji publicznej.

W ramach czwartej sekcji omówione zostały problemy tradycji oraz nowatorstwa w literaturze ukraińskiej XX wieku. Kandydatka nauk filologicznych, docentka Oksana Kuźma (Użhorod) zaproponowała analizę porównawczą utworów dramatycznych Łesi Ukrainki i Spyrydona Czerkasenki. Główny akcent w tym referacie położono na aspekty intertekstualne, obecne w tekstach obojga autorów. Do dorobku pisarskiego Łesi Ukrainki odwołała się również profesorka dr hab. Tetiana Mejzerska (Kijów), która zaproponowała omówienie kinowych adaptacji dramatu (Kamienny gospodarz). Profesorka dr hab. Olha Turhan (Zaporoże) w sposób niekonwencjonalny zaprezentowała aspekty genderowe w literaturze pięknej. Podczas jej wystąpienia wybrzmiała analiza obrazu Safony w twórczości pisarzy ukraińskich z okresu modernizmu. Profesorka dr hab. Witalina Kyzyłowa (Ługańsk - Starobielsk) opowiedziała o różnorodności tematycznej współczesnych baśni, natomiast profesorka dr hab. Żanna Jankowska (Ostróg) wyeksponowała paralele z założeniami filozofii egzystencjalnej, obecnej w powieści wierszowanej Marusia Czuraj wybitnej współczesnej poetki Ukrainy Liny Kostenko. Powieść, którą uznano za arcydzieło literatury ukraińskiej, bez wątpienia zasługuje na nowe 
oryginalne interpretacje badaczy ukrainistów. Doktorantka Swittana Kondratiewa (Kijów) eksplorowała dramat Duma o Brytance Jurija Janowskiego. Na podstawie analizy rękopisu pisarza oraz okoliczności jego powstania badaczka omówiła powiązania dramatu $\mathrm{z}$ dramaturgią radziecką, utrzymaną w konwencji realizmu socjalistycznego. Profesor dr hab. Jarosław Poliszczuk (Poznań) zaproponował wyjątkowe, retrospektywne spojrzenie na literaturę ukraińską XX wieku. Swoją uwagę skupił na funkcjonowaniu literatury jako swoistej instytucji społeczno-kulturowej oraz swego rodzaju twórczości, przeanalizował praktykę reinterpretowania kanonu literackiego XX wieku.

Różnorodność opinii oraz interpretacji w zakresie współczesnej literatury ukraińskiej stała się przedmiotem ciekawej refleksji uczestników piątej sekcji konferencji „Ukrainistyka: wczoraj, dzisiaj, jutro...”. Docentka dr hab. Oksana Puchońska (Ostróg) prześledziła recepcję posttotalitarnych wojen, odnosząc się do ukraińskiego i bałkańskiego kontekstu literackiego. Doktor Ryszard Kupidura (Poznań), odwołując się do reguł literatury migracyjnej, zanalizował stereotypy narodowe oraz aspekt współczesnych migrantów na przykładzie autobiograficznego reportażu Polak z Ukrainy Dimy Harbowskiego. Doktorantka Daryna Hładun (Kijów) przeprowadziła rekonesans badawczy problematyki współczesnego performansu poetyckiego w Ukrainie. Jej zdaniem, stan badań nad tym zagadnieniem wśród ukraińskich uczonych jest niewystarczający. Doktorka Ołena Weszczykowa (Zaporoże) przeanalizowała powieść Iłłariona Pawluka Biały popiót. Autorka referatu skupiła się na ujawnieniu strategii narracyjnych wskazanego wyżej tekstu. Doktorka Natalia Daszko (Dniepr) zapoznała słuchaczy ze stylistyczną polifonicznością utworów kolejnego współczesnego autora, nowelisty Wołodymyra Nazarenki. Profesorka dr hab. Maria Szymczyszyn (Kijów) scharakteryzowała przestrzeń obczyzny w wizji artystycznej amerykańskiego pisarza o ukraińskich korzeniach Askolda Melnyczuka na postawie jego powieści Co zostało powiedziane, natomiast wykładowczyni Olga Nowodworczuk (Krzemieńczuk) odwołała się do twórczości dla dzieci w wieku przedszkolnym, akcentując tendencje gatunkowo-ideograficzne tejże literatury.

Należy podkreślić, iż w każdej z wymienionych sekcji panowała atmosfera dynamicznego polilogu, wymiana doświadczeń i poglądów naukowych, ożywione dyskusje. Jak zauważyli sami uczestnicy i uczestniczki konferencji, z powodu długotrwałego przebywania w warunkach pandemicznej izolacji, i po części ograniczenia aktywności twórczej, znacznie wzrosła potrzeba wymiany myśli, zwłaszcza w kręgach naukowych. To bez wątpienia znalazło swoje odbicie w niezwykłej aurze towarzyszącej pamiętnemu spotkaniu ukrainistek i ukrainistów, przyczyniło się do wzmocnienia zawartych w tych dniach kontaktów naukowych i osobistych.

Ostatnim, niewątpliwie oryginalnym i udanym akcentem V Międzynarodowej Konferencji Naukowej Ukrainistów w Poznaniu był okrągły stół pt. „Ukraiński noir 
i twórczość Ołesia Ulianenki”, który miał miejsce 23 października w godz. 10.0013.00. Organizatorką tego wydarzenia była doktorka habilitowana, profesorka w Zakładzie Ukrainistyki Uniwersytetu im. Adama Mickiewicza Anna Horniatko-Szumiłowicz, która razem ze znaną slawistką, profesorką UAM Marzanna Kuczyńską kierowała dyskusją. W programie znalazło się sześć wystąpień, z których każde w sposób oryginalny naświetlało twórczość znakomitego ukraińskiego pisarza Ołesia Ulianenki, zwłaszcza w szerokim kontekście kulturowym i społecznym. Jako pierwsza wystąpiła profesorka Marzanna Kuczyńska (Poznań), która podzieliła się wnikliwą i obszerną refleksją na temat słowiańskiego noir. Prelegentka skupiła się na porównaniu dwóch wersji literatury noir - bułgarskiej i ukraińskiej, kompleksowo przeanalizowała ich podobieństwa i różnice, które dobrze oddają charakter specyfiki narodowej obu literatur. Profesor dr hab. Feliks Sztejnbuk (Bratysława) odwołał się do budzących wiele kontrowersji wyróżników gatunkowych prozy Ołesia Ulianenki, a tytuł jego referatu - „Noir bez noir w powieści Ołesia Ulianenki «Kwiaty Sodomy»" - odzwierciedlał polemiczny charakter wystąpienia. Kolejny prelegent, doktorant Przemystaw Lis-Markiewicz (Poznań - Wrocław) w swym wystąpieniu rozwinął określoną poprzednio polemikę wokół twórczości autora Kwiatów Sodomy. O ile wspomniana książka, w przekonaniu młodego badacza, wykazuje wszystkie typowe oznaki prozy artystycznej w gatunku noir, o tyle pozostałe utwory pisarza reprezentują różne cechy gatunkowe. Inspirujące było wystąpienie reżysera i bliskiego przyjaciela pisarza Myrosława Staboszpyckiego (Kijów). W referacie pt. „Synergia kina masowego i literatury w twórczości Ołesia Ulianenki” reżyser przedstawił charakterystyczne konteksty literackie i artystyczne, do których powinni odwoływać się badacze tego oryginalnego twórcy. Nierozstrzygniętą kwestią dorobku wspomnianego prozaika, wybrzmiewającą w interesującym wystąpieniu profesorki UAM dr hab. Anny Horniatko-Szumiłowicz (Poznań), była symultaniczność motywów okrucieństwa i czułości, co dobrze zilustrował przywołany w referacie cytat - „I chcę to zrobić... zabić - wchodząc w miłosierdzie....". Obrady zwieńczyła naukowa wypowiedź doktorantki Anastazji Jaremczuk (Poznań) na temat percepcji zmysłowej opowiadania Chi-chi-i! znanego pisarza Jurija Wynnyczuka. W obradach okrągłego stołu wzięło udział trzydziestu uczestników. Ożywiona debata, która towarzyszyła tej części konferencji, świadczyła o zainteresowaniu słuchaczy przestawioną przez prelegentów problematyką, była swoistym dowodem uznania dla gatunku i formy noir we współczesnej literaturze ukraińskiej. Wydaje się, że taka koncepcja spotkania była też dobrą okazją do refleksji nad wybitną i wciąż mało zbadaną twórczością przedwcześnie zmarłego pisarza. 